\title{
Identification non-timber forest products as a source of halal food for village communities around the forest
}

\author{
Siti Latifah $^{1 *}$, Agus Purwoko ${ }^{1}$, Khaira Amalia Fachrudin ${ }^{2}$, and Jeffry William Siregar ${ }^{1}$ \\ ${ }^{1}$ Forestry Faculty, Universitas Sumatera Utara, Jl. Tri Dharma, Medan, 20155, Sumatera Utara, \\ Indonesia \\ ${ }^{2}$ Economics Faculty, Universitas Sumatera Utara, Jl. Prof. T. M. Hanafiah, Medan, 20155, Sumatera \\ Utara, Indonesia
}

\begin{abstract}
The community's reliance on logging forest resources has reached the limit of its carrying capacity. Non-timber forest products are one type of natural resource that can help limit the direct use of timber forest products. Interviewing techniques and field observation were used to acquire data. The findings show that Arenga pinnata and other non-timber forest products (NTFPs) have economic potential as halal foods are Arenga pinnata, Hevea brasiliensis, Durio zibethinus, Areca catechu, Theobroma cacao, Parkia speciosa, Lansium parasiticum, and Archidendron pauciflorum.
\end{abstract}

\section{Introduction}

Non-timber forest products are examples of forest resources with a comparative advantage and direct contact with the surrounding community[1]. According to [2,] NTFPs that can be used for domestic or industrial purposes include food or additives, grains, mushrooms, molds, fruits, herbs, spices, aromatic plants, fibers (used for construction, furniture, clothing, or equipment), resins, rubber, and plants and animals used for medicine, cosmetics, and ceremonial (religious and cultural) purposes.. By utilizing NTFPs, communities can directly minimize the exploitation of timber forest products.

Non-timber forest products are one of the forest resources with a comparative advantage, and they have direct contact with local communities [1].According to [2,] food or additives, seeds, mushrooms, fungi, fruits, herbs, herbs and spices, aromatic plants, fiber (used in construction, furniture, clothing, or equipment), resin, rubber, plants and animals used for medicine, cosmetics, and ceremonial purposes (religion and culture) are all examples of NTFPs that can be used for household or industrial purposes.

The community can directly reduce the exploitation of timber forest products by using NTFPs . Based on this, the study was carried out to create an inventory of the types of Non Timber Forest Products (NTFP's) that are used as halal food by the community around the forest.

\footnotetext{
* Corresponding author: sitilatifah164@yahoo.co.id
} 


\section{Research Methods}

This research was conducted from January to March 2021, located in Sigiring Giring village, Tukka District, Center Tapanuli Regency, North Sumatera. Data collection was obtained from interviews with respondents who took non-timber forest products around the forest.

Purposive sampling was used as the sampling approach (samples of purpose). Purposive sampling refers to the selection of respondents from rural populations who take or use NTFPs that are customized to the study's goals.

Gender, age, number of family members, education level, and kind and use of NTFPs are among the field data gathered by questioning the head of home.The information gathered was then assembled and analyzed quantitatively. The following provisions apply to the number of respondents polled[3]:

1) If the total population of NTFP-using families is fewer than 100, all respondents are taken.

2) If there were more than 100 heads of families who took NTFPs, $10 \%$ to $15 \%$ of the total heads of families took NTFPs.

The respondents were separated into two groups, namely (i) general respondents and (ii) forest communities in Sigiringgiring Village who are familiar with non-timber forest products. Village heads, tribal leaders, religious leaders, and other community leaders are among the main respondents.

The results of focus groups, interviews with resource people, and field survey results were used to assess the data.The information from the interviews was transcribed into a quantitative format.

\section{Discussion of the findings}

\subsection{Respondent Identity}

Respondents in this study were 98 families in Sigiring Giring village who used NTFP's. The respondents in this study were 98 families in Sigiring Giring village who used NTFP. With a ratio of $94 \%$, men represent the majority of responders to the usage of non-timber forest products (NTFPs). This is because a man is the head of the family, who has the obligation to earn a living and meet the daily economic needs of the family. [4].

Based on the results of the interview, it is known that respondents from Sigiring Giring Village are dominated by groups of people aged between 41-55 years, as many as 35 families $(36 \%)$ who use NTFPs the most. Based on this information, The people who make the most use of forest resources are in the productive age range. The large number of people using forest resources who are included in the productive age group indicates that there are limited employment opportunities outside the forestry sector in the area [5] [6].

The size of the number of family members who use forest resources also has an effect on increasing and decreasing the use of $f$ est resources, where the bigger a family, the greater the availability of labor. The number of dependents of the respondent's family who used the most NTFPs was 1-5 people, as many as 75 families (75\%).

The number of workers working to make use of influential forest resources depends directly on the amount of forest resources used and the amount of family income. Because many family members are either too young (children) or too old (adults) to take advantage of forest resources, not all family members can benefit from them [5].

The use of non-timber forest products is directly related to a person's level of education when considered from that perspective (NTFP). Most of the people in Sigiring Giring 
Village who use NTFPs have a high school education background, as many as 63 families (64\%). It can be argued that NTFP users have a reasonably high level of education (Table 1). The level of community education affects the level of utilization of forest resources. This is related to the knowledge possessed, mastery of technology, skills, and market information obtained. If a person's education is higher, the knowledge obtained is likewise higher, allowing them to process and develop non-timber forest products (NTFPs) more effectively. [2, 3]. The respondent's identity is shown in Table 1 below.

Table 1. Respondent's identity

\begin{tabular}{|c|c|c|c|}
\hline No & $\begin{array}{l}\text { The identity of the } \\
\text { respondent }\end{array}$ & $\begin{array}{l}\text { Number of } \\
\text { respondents }\end{array}$ & Percentage $(\%)$ \\
\hline 1 & $\begin{array}{l}\text { Gender } \\
\text { - Male } \\
\text { - Female }\end{array}$ & $\begin{array}{c}92 \\
6\end{array}$ & $\begin{array}{c}94 \% \\
6 \%\end{array}$ \\
\hline 2 & $\begin{array}{l}\text { Age ( year) } \\
-<30 \\
-31-40 \\
-41-55 \\
->56\end{array}$ & $\begin{array}{c}28 \\
33 \\
35 \\
2\end{array}$ & $\begin{array}{c}29 \% \\
34 \% \\
36 \% \\
1 \%\end{array}$ \\
\hline 3 & $\begin{array}{l}\text { The number of people borne } \\
\text { by the head of the family } \\
\text { - } 1-4 \text { people } \\
\text { - } \geq 5 \text { people }\end{array}$ & $\begin{array}{l}75 \\
23\end{array}$ & $\begin{array}{l}77 \% \\
23 \%\end{array}$ \\
\hline 4 & $\begin{array}{l}\text { Level of education } \\
\text { - primary school } \\
\text { - middle school level } \\
\text { - high school }\end{array}$ & $\begin{array}{c}27 \\
8 \\
63\end{array}$ & $\begin{array}{l}28 \% \\
8 \% \\
64 \%\end{array}$ \\
\hline
\end{tabular}

\subsection{Identification non-timber forest products (NTFP's) as a source of halal food}

The majority of rural households and a considerable number of urban households in many developing countries, including Indonesia, rely on NTFPs for part of their food, health, building materials, and income from selling these items [7]. Muslim communities living near the forest require halal NTFH information. Halal is an Arabic term which means permissible. All food that can be eaten according to Islamic teachings is called halal food. In Islam, all food and drink is halal, except for those that are explicitly prohibited in the Qur'an. Number of NTFP Utilization can be seen on figure 1 below. 


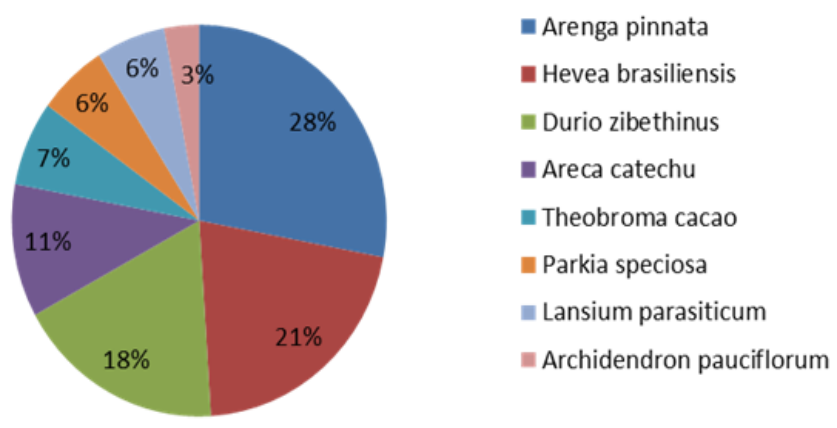

Fig. 1. Number of NTFP Utilization

Forests can aid local communities financially by collecting and selling non-timber forest products [6].Table 2 shows the identification of non-timber forest products used by the community based on the findings of the field investigation.Forests can provide economic benefit to local communities by exploitation and sale of non-timber forest products $[6,8]$. By harvesting and selling non-timber forest products, forests can add economic value to the local community [6]. The number of individuals who rely on the forest for labor and money, as well as the rural communities' dependency on forest resources $[6,1]$.

According to a study conducted on 98 respondents from the community in Sigiringgiring Village, sugar palm was the most commonly used forest product by respondents, accounting for 27 families or 28 percent of the total respondents. There were 21 families or $21 \%$ of respondents who used NTFP in the form of rubber, followed by the Durio zibethinus fruit, which was used by 18 families or $18 \%$ of respondents. Areca catechu, used by 11 families or $11 \%$ of respondents, cacao, used by 7 families or $7 \%$ of respondents, Parkia speciosa, used by 6 families or $6 \%$ of respondents, and Lansium parasiticum, used by 6 families or $6 \%$ of respondents. Archidendron pauciflorum was the least used NTFP, accounting for 2 families or 3\% of the total (Fig. 1). Table 2 below shows the Identification of Non-Timber Forest Products ( NTFPs).

Table 2. Identification of Non-Timber Forest Products ( NTFPs)

\begin{tabular}{|c|c|c|c|c|}
\hline No & $\begin{array}{l}\text { Types of } \\
\text { NTPFs }\end{array}$ & family & $\begin{array}{c}\text { NTFPs } \\
\text { part used }\end{array}$ & Benefit \\
\hline 1 & $\begin{array}{l}\text { Sugar palm } \\
\text { (Arenga } \\
\text { pinnata) }\end{array}$ & Arecaceae & Fruit, leave & $\begin{array}{l}\text { - Palm sugar helps to treat } \\
\text { anemia, improves heart and } \\
\text { intestinal health, and promotes } \\
\text { body immunity. } \\
\text { - Used to build a house's roof }\end{array}$ \\
\hline 2 & $\begin{array}{l}\text { Rubber } \\
\text { (Hevea } \\
\text { brasiliensis) }\end{array}$ & Euphorbiaceae & Rubber & $\begin{array}{l}\text { - Latex } \\
\text { - Rubber sap that is processed } \\
\text { according to the procedure can } \\
\text { be a mixture of snacks, cakes, } \\
\text { and even baby food. }\end{array}$ \\
\hline 3 & $\begin{array}{l}\text { Durian } \\
\text { (Durio } \\
\text { zibethinus) }\end{array}$ & Malvaceae & fruit & $\begin{array}{l}\text { - } \text { Fress fruit } \\
\text { - Fradisional food } \\
\text { - Durian fruit is rich in } \\
\text { antioxidants which are good for }\end{array}$ \\
\hline
\end{tabular}




\begin{tabular}{|c|c|c|c|c|}
\hline & & & & $\begin{array}{l}\text { body health, contains vitamin } \mathrm{E} \\
\text { and beta carotene which can } \\
\text { help increase endurance. }\end{array}$ \\
\hline 4 & $\begin{array}{l}\text { Aareca nut } \\
\text { palm, } \\
\text { (Areca } \\
\text { catechu) }\end{array}$ & Aracaceae & Fruit, leave & $\begin{array}{l}\text { - solves digestive issues, removes } \\
\text { toxins from the body, and } \\
\text { stimulates appetite } \\
\text { - When chewing betel nut, folks } \\
\text { mix these seeds in with it. } \\
\text { - the roof of a house }\end{array}$ \\
\hline 5 & $\begin{array}{l}\text { Cacao } \\
\text { (Theobroma } \\
\text { cacao) }\end{array}$ & Malvaceae & $\begin{array}{l}\text { Fruit, } \\
\text { seed }\end{array}$ & $\begin{array}{l}\text { - The seeds of this fruit are also a } \\
\text { source of monounsaturated fats } \\
\text { which are very good for health. } \\
\text { Even the seeds also contain } \\
\text { vitamins, minerals, fiber, natural } \\
\text { carbohydrates, and proteins that } \\
\text { are good for health }\end{array}$ \\
\hline 6 & $\begin{array}{l}\text { Petai } \\
\text { (Parkia } \\
\text { speciosa) }\end{array}$ & Fabaceae & fruit & $\begin{array}{l}\text { - Tradisional food } \\
\text { - As vegetable fress } \\
\text { contains tryptophan compounds } \\
\text { and proteins that will act as } \\
\text { serotonin to deal with stress or } \\
\text { depression }\end{array}$ \\
\hline 7 & $\begin{array}{l}\text { Langsat } \\
\text { (Lansium } \\
\text { parasiticum) }\end{array}$ & Meliaceae & fruit & $\begin{array}{l}\text { - fress fruit } \\
\text { - Fruit fiber is good for digestion, } \\
\text { fruit peel as an antioxidant, seed } \\
\text { powder can be used as a fever } \\
\text { medicine, Langsat tree bark as } \\
\text { an anti-insect bite Medicine. } \\
\text { - moisturizing skin }\end{array}$ \\
\hline 8 & $\begin{array}{l}\text { Jengkol } \\
\text { (Archidendron } \\
\text { pauciflorum) }\end{array}$ & Fabaceae & fruit. & $\begin{array}{l}\text { - Tradisioanl food } \\
\text { - used for various dishes such as } \\
\text { stews, a mixture of fried chili } \\
\text { sauce, a mixture of rendang, to } \\
\text { become fresh vegetables. } \\
\text { - as traditional medicine such as } \\
\text { preventing anemia, controlling } \\
\text { blood pressure }\end{array}$ \\
\hline
\end{tabular}

Forest products such as fruits, leaves, sap, and palm fiber are used by communities near the forest. NTFPs can be found in foods, beverages, pharmaceuticals, cosmetics, appliances, and home products [3]. Non-timber items, including non-market and market facilities, play an essential role in addressing community needs $[9,10]$. Non-Timber Forest Products (HHBK) may become more important in local people' daily lives as a result of this [11]. 
Village communities' socio-economic activities in the forest to meet their daily needs are a manifestation of community engagement with the natural environment in the form of forests [12].Forest populations rely on forests to meet their basic needs, particularly halal food sources, in their daily lives [13].

\section{Conclusion}

The people of Sigiring Giring use NTFPs as a source of halal food, namely Arenga pinnata and Hevea brasiliensis. Durio zibethinus, Areca catechu, Theobroma cacao, Parkia speciosa, Lansium parasiticum, and Archidendron pauciflorum are among the plants. The community that surrounds the forest relies on the forest's existence to meet their daily requirements.

The authors would like to express their gratitude to the villagers who volunteered to be responders in the study.We'd like to express our gratitude to the University of North Sumatra Research Institute for aiding us with research and publishing.

\section{References}

1. M. Schaafsma, S. M. Jones, P. Posen and R. D. Swetnam, Ecological Economics, 80, 48-62 (2012)

2. A. K. Pandey, P. Bhargava and M.S. Negi, Indian Forester, 137, 105-113 (2011)

3. S. Latifah, A. Purwoko, K. A. Fachrudin, N. S. T. Dahriyanti. IOP Conference Series: Earth and Environmental Science, 782, 032028 (2021).

4. A. Asfaw, M. Lemenih, H. Kassa and Z. Ewnetu, Forest. Policy. Econ. 28, 1-7 (2013)

5. I. S. Nugraha and Aprizal Alamsyah, Journal of Agricultural Sciences (JIPI), 24, 93-100 (2019)

6. S. Latifah, N. A. Lubis, K. A. Fachrudin, A. Purwoko, International Conference on Science and Technology, 1542, 012035 (2020)

7. K. Heubach, R. Wittig, E. A. Nuppenau, and K. Hahn. Human Ecology, 41, 513-533 (2013)

8. A. Ahenkan and E. Boon, Journal of Food Agriculture \& Environment, 8, 962-96 (2010)

9. J. W. Siregar. Sebaran, Nilai Ekonomi dan Kontribusi Hasil Hutan Bukan Kayu Terhadap Pendapatan Masyarakat Desa Sigiringgiring Kecamatan Tukka Kabupaten Tapanuli Tengah, Skripsi, Departemen Manajemen Hutan Fakultas Kehutanan, (Universitas Sumatera Utara Medan, Medan, 2021)

10. E.Y. Karyon, R. Emi and N. R. Joko, Journal of Sustainable Forests, 4, 14-21 (2016)

11. R. T. Hutauruk, A. M. Lahjie, B.D.A.S. Simarangkir, M. I. Aipassa, and Y. Ruslim, Biodiversitas, 19, 421-430 (2018)

12. S. Latifah and A. Lubis, IOP Conf. Series: Earth and Environmental Science, 454 (2020)

13. S. Latifah, Y. Afifuddin, and S. Widya. Proceeding series of Earth and Environmental Science International Conference on Agriculture, Environment, and Food Security, 122, (2017) 